\title{
AL-GHAZALI DAN KRITIKNYA TERHADAP FILOSOF
}

Oleh

\section{Muliati}

\begin{abstract}
Abstrak
Kritikan al-Ghazali terhadap filosof sebagaimana yang dirumuskan dalam Tahafut al Falasifah seringkali dijadikan alasan bagi reinkarnasi pemikiran di dunia Islam, karena meskipun kritikan tersebut terbatas pada teori metafisika (Al-Ilahiyat), akan tetapi sering digeneralisir sebagai kritik terhadap keseluruhan kajian filsafat, sehingga filsafat tercampakkan ke posisi marginal dalam pemikiran Islam. Untuk itu, perlu adanya klarifikasi dan upaya meluruskan kembali persepsi tersebut, khususnya dikalangan akademisi. Ada dua puluh masalah yang disajikan baik kritikan oleh al-Ghazali. Tujuh belas masalah yang dikategorikannya sebagai bid'ah dan tiga lainnya dicap kafir. Ketiga masalah tersebut itu adalah keqadiman alam, ketidaktahuan Tuhan terhadap hal yang kecil (juz'iyat) dan tidak adanya kebangkitan jasmani.
\end{abstract}

\section{Keyword: \\ Al-Ghazali, Tahafut al Falasifah, Filsafat, Kritik Filosof}

\section{PENDAHULUAN}

A. Latar Belakang Masalah

Salah satu faktor yang memungkinkan filsafat Yunani dikaji oleh umat Muslim adalah karena adanya karya-karya terjemahan filsafat yang disalin ke dalam bahasa Arab, baik yang langsung dari filsafat Yunani maupun dari teks asli versi Syiria. ${ }^{1}$ Gerakan penerjemahan ini berlangsung dari abad ke-8 sampai ke-11 $\mathrm{M}^{2}$

Melalui penerjemahan ini para pemikir muslim mengenal pemikiran para filosof Yunani seperti Plato, Aristoteles dan ajaran Neo-Platonis. Mereka kemudian mengembangkannya dengan nuansa Islam, sehingga lahirlah sebutan filsafat Islam dengan beberapa tokohnya seperti al-Kindi (796-873 M ), al-Farabi (870-950 M), Ibnu Sina (980-1037 M), al-Ghazali (1058-1111 M), Ibnu Rusyd (1126-1198 M) dsb. ${ }^{3}$

Mereka memiliki reputasi dan pengaruh yang diakui tidak hanya di dunia Islam abad pertengahan, bahkan juga mewarnai filosof muslim kekinian. Watt mengambil kesimpulan bahwa tanpa keberadaan mereka, ilmu pengetahuan dan filsafat orang-orang Eropa tidak dapat berkembang seperti ketika nenek moyang mereka mengembangkannya untuk pertama kalinya. ${ }^{4}$

\footnotetext{
${ }^{1}$ Lihat, Harun Nasution. Filsafat dan Mistisisme dalam Islam (Cet, I : Jakarta : Bulan Bintang. 1992), h. II

${ }_{2}$ Majid Fakhriy. A History of Islamic Philosophy. Diterjemahkan oleh R. Mulyadi Kartanegara dengan judul "Sejarah Filsafat Islam “(Cet. I : Jakarta : Pustaka Jaya. 1987). h. 33-34.

${ }^{3}$ Lihat. Amin Abdullah. Agama Normativitas atau Historitas (Cet. I : Yogyakarta : Pustaka Pelajar, 1996). h. 265

${ }^{4}$ W. Montgomery Wati. The Influence of Islam on Medieval Europe. Diterjemahkan oleh Hendro Prasetio dengan judul “ Islam dan Peradaban Dunia,. Pengaruh Islam Atas Eropa Abad Pertengahan " ( Jakarta : Gramedia. 1995). h. 59-62.
} 
Filsafat Islam mencapai puncaknya pada abad ke-9 dan ke-11 M. Berbeda dengan filsafat Barat yang berkembang hingga abad modern. Sementara filsafat Islam tidak mampu melampaui abad pertengahan dan mulai memasuki periode anti klimaks pada abad ke-12 M, khususnya pasca Ibnu Rusyd.

Di antara filosof muslim abad pertengahan, al Ghazali termasuk tokoh yang fenomenal. Disamping sebagai seorang filosof, ia juga melakukan perlawanan terhadap pemikiran filsafat pada masa itu dengan mengemukakan kritik sistematis terhadap filosof.

Kritiknya terhadap filsafat, sebagaimana termuat dalam karyanya Tahafut al-Falasifah, disinyalir mampu menghidupkan filsafat di dunia Islam dan menentukan jalannya sejarah pemikiran umat Islam berikutnya. ${ }^{5}$ Bahkan ada semacam persepsi bahwa stagnasi pemikiran di dunia Islam adalah akibat dari kritik al-Ghazali tersebut, meskipun tesis ini bisa diuji kembali validitasnya.

Memang kritik al-Ghazali tersebut sampai pada pengkafiran beberapa filosof Muslim dan menempatkan filsafat Islam pada posisi marginal.

Al Ghazali dalam karyannya yang berjudul Maqashid Al Falsafah, secara jelas memilah kajian filsafat menjadi empat aspek yaitu : ilmu pasti, matafisika, logika dan ilmu-ilmu alam. ${ }^{6}$

Ilmu pasti seperti ilmu matematika dan ilmu teknik, menurut al-Ghazali adalah kebenaran yang harus diterima dan tidak bisa diingkari. Begitu pula logika, hampir keseluruhan teori di dalamnya adalah benar. Jika tidak terdapat kesalahan biasanya hanya pada aspek penggunaan terminologi dan bukan pada makna substansinya. Sementara, dalam hal ilmu alam, digeneralisasikan karena di dalamnya bercampur antara kebenaran dan kesalahan. Sedangkan, dalam hal metafisika, al-Ghazali secara tegas menyatakan bahwa sebagian besar teori para filosof tidak sejalan dengan agama. ${ }^{7}$ Disinilah al-Ghazali memusatkan kritikkritiknya.

Berdasarkan uraian di atas, maka yang menjadi permasalahan pokok dalam makalah ini adalah bagaimana kritik Al Ghazali terhadap filsafat ?.

\section{B. Metodologi Penelitian}

Dalam penulisan makalah ini, penulis menggunakan metode Library Research, yaitu dengan mengumpulkan bahan-bahan dari literatur- literatur yang terkait dengan masalah yang dibahas.

Bahan-bahan yang telah dihimpun, selanjutnya disusun dan dianalisa dengan menggunakan metode induktif dan deduktif.

C. Signifikansi Pembahasan

Tulisan ini akan menguraikan pemikiran-pemikiran al-Ghazali ketika memberikan tanggapan dan kritik terhadap para filosof Muslim yang mendahuluinya seperti al-Kindi, al-Farabi dan Ibnu Sina. Karena uraian itu hanya bersifat penjelajahan pemikiran, maka sifatnya eksplorasi.

\footnotetext{
${ }^{5}$ Lihat. Nurcholish Majid. Khazanah Intelektual Islam (Cet. II : Jakarta : Bulan Bintang, 1994). h. 35.

${ }^{6}$ Imam al-Ghazali. Maqashid al Falasifah. Edisi Sulaiman Dunya (Mesir : Dar al-Ma'arif, t.th). h. 31 .

${ }^{7}$ Lihat. Ibid., h. 31-32
} 


\section{RIWAYAT HIDUP AL GHAZALI DAN KARYA-KARYANYA}

Nama lengkap adalah Abu Hamid Muhammad ibn Muhammad ibn Ahmad al-Ghazali al-Tusi. Penulisan nama al-Ghazali atau al-Ghazzali sebagai namanya menjadi kontroversi, tetapi kelahirannya dipastikan pada $450 \mathrm{H} / 1058 \mathrm{M}$ di Ghazaleh, suatu desa dekat Thus, di daerah Khurasan, Persia. Sekitar dua puluh tahun setelah kematian Ibnu Sina, dimana pemikiran filsafat pada saat itu telah berkembang pesat hingga mempunyai kedudukan yang lebih tinggi dari teolog. ${ }^{8}$

Ia memiliki saudara bernama Ahmad yang terkenal sebagai sufi, ketika ia memusatkan perhatiannya pada ilmu fiqih dengan salah satu gurunya yang bernama al-Razakani di Thus. Setelah itu ia merantau ke Jurjan dan berguru pada Abu Qasim al-Ismaili. ${ }^{9}$ Kemudian sekitar tahun $1077 \mathrm{M}$ al-Ghazali meneruskan studinya ke Naisabur dan berguru pada seorang ulama termasyur yaitu al-Juwaini, dan tinggal disana hingga meninggal dunia pada tahun $1058 \mathrm{M}$. Kemudian pergi ke Mu'asykar Nizam al-Mulk, perdana menteri Bani Seljuk, ia memperoleh tempat terhormat di antara para sarjana di sana, hingga pada tahun $1091 \mathrm{M}$ ketika masih sangat muda, ia ditunjuk menjadi staf guru besar pada Perguruan Tinggi Nizamiyah di Baghdad.

Ia mengajar di sana selama empat tahun dan pada waktu itulah ia menyusun bukunya Maqasid al Falasifah (pemikiran kaum filosof) yang diterjemahkan ke dalam bahasa latin dengan judul Logika act Philosophia algazelis Arabis pada tahun 1145 M oleh Dominikus Gundissalinus. Demikian pula buku yang lain seperti Tahaful al Falasifah. ${ }^{10}$

Dalam banyak hal al-Ghazali adalah penerus langsung peranan al-Asy'ari, sebagaimana al-Asy'ari dengan meminjam metode Mu'tazilah berhasil merumuskan dan mengkordinasikan faham Sunni. Demikian juga al-Ghazali, dengan meminjam metode lawannya yakni Neo-Platonisme dan Aristotelianisme, ia berhasil membendung bahaya gelombang Hellenisme yang kedua, sebagaimana sebelumnya al-Asy'ari melakukan hal yang sama untuk membendung Hellenisme yang pertama. Maka al-Ghazali mendapat gelar "hujjatul al Islam" dan menjadi simbol bagi kaum Sunni. ${ }^{11}$

Disamping ia dikenal sebagai tokoh dalam bidang filsafat, al-Ghazali juga dikenal sebagai teolog dan sufi. Bermula dari keraguannya terhadap kebenaran yang ia peroleh, ia melakukan pengkajian yang lebih serius dalam rangka pencarian kebenaran hakiki, kebenaran yang tidak mengandung keraguan sama sekali. al-Ghazali, setelah melalui perjalanan panjang, menyelidiki secara seksama hasil yang dicapai dalam empat golongan "pencari kebenaran" yang ada pada zamannya yakni Mutakallimin (teolog), Bathiniyah (pengikut Syi'ah Isma'iliyah), filosof dan sufi, akhirnya ia berkesimpulan bahwa kehidupan sufilah yang dapat mengantarkannya kepada kebenaran sejati. ${ }^{12}$

\footnotetext{
${ }^{8}$ Lihat Yusuf Musa. Bavn al-Din wa al-Falsafah fi Ra'vi Ibnu Rusyd wa al-Falasifah alAsr al-Waisth. (Cet. I : Mesir, t.th). h. 188

${ }^{9}$ Lihat. Majid Fakhry. on. cit., h. 304.

${ }^{10}$ Lihat. Harun Nasution. Islam Ditinjau dari Berbagai aspeknya. Jilid II (Cet. VI Jakarta : UI-Press. 1986), h. 52-53.

${ }^{11}$ Lihat. Nurcholish Majid. op.cit., h.34.

12 Lihat. Fakhriyah Hasan Sulaiman. Mazahid fi al Tarbiyah :Bahts fi al Mazhab al tarwabity Inda al Ghazali (Cet. II: Mesir : Maktabah al Wahdlah. 1964). h. 7.
} 
Akhirnya pada tahun $1095 \mathrm{M}$ ketika hendak melaksanakan ibadah haji ke Mekah, ia meninggalkan Baghdad dan mengundurkan diri dari dunia akademis di Baghdad. Alasan pengunduran dirinya ini tidak diketahui secara pasti. Yang jelas sejak itu, ia mengubah pola hidupnya untuk mengabdi kepada Allah swt, sebagai seorang sufi.

Dari Baghdad, al-Ghazali tidak langsung ke Mekah untuk beribadah haji, tetapi ke Damaskus, Baitul Maqdis baru ke Mekah, Madinah dan berpindah-pindah antara Syam, Baitul Maqdis dan Hijaz, hingga pada tahun 1106 M al-Ghazali kembali ke Naisabur untuk mengajar di Madrasah Nizamiyah. Pada tahun $1107 \mathrm{M}$, ia kembali di kota kelahirannya di Thus dalam kehidupan sebagai seorang sufi hingga ia meninggal dunia pada hari Senin, 14 Jumadil Akhir $505 \mathrm{H} / 1111 \mathrm{M}^{13}$

Adapun karya-karyanya antara lain : 1) Ihya Ulumuddin, 2) al-Adab fi alDin, 3) al-Arba'in fi Ushul al-Din, 4) Assas al-Qiyas, 5) al-Istidraj, 6) Asrar Mu'amalah al-Din, 7) al-Iqtishad fi al-I'tiqad, 8) Ilja al-Awwan al-Ilmu al-Kalam, 9) al-Isma' ala Musykil al-Ihya, 10) Ayyuha al-Walad, 11) al-Bab al-Muntahal fi al-Jidal, 12) Bidayah al-Hidayah, 13) al-Basith fi al-Furu', 14) Ghayah al-Ghawr fi Dirayah al-Dawr, 15) al-Tawilah, 16) al-Tibral al-Masbuq fi Nasha'I al-Mulk, 17) Tashim al-Ma'akid, 18) Talbis Iblis, 19) al-Talikaf fi Furu' al-Mazhab, 20) alTafriqah bayn al-Islam wa al-Zandaqah, 21) Tafsir al-Qur'an al-Azhim, 22) Tazhib al-Ushul, 23) al-Mungkidz min al-Dhalal, 24) Tahafut al-Falasifah, 25) Maqasid al-Falasifah, 26) al-Wajiz, 27) Lubab al-Nazhar, 28) Qawashim al-Bathiniyah, 29) Kimiyah al-Sa'adah. ${ }^{14}$

Jadi, karya-karya al-Ghazali tidak menjadi konsumsi masyarakat secara umum, tetapi ada klasifikasinya. Ada yang diperuntukkan kepada para ahli tasawuf dan ada pula kepada pakar etika. Oleh karena itu, karya-karyanya ada yang berbeda satu dengan lainnya.

\section{KRITIK AL-GHAZALI TERHADAP FILOSOF}

Al-Ghazali membagi para filosof kedalam tiga kelompok, yang masingmasing memiliki pemikiran yang berbeda. Akan tetapi, kesemuanya tidak luput dari tanda-tanda kekufuran.

Pertama, filosof Materialis (al Dhariyyun), mereka adalah Atheis yang menyangkal adanya Allah serta merumuskan kekekalan alam dan terciptanya alam dengan sendirinya. Kedua, filosof Naturalis atau Deistis (Thabi'iyyun), mereka melaksanakan berbagai riset terhadap alam semesta, hewan dan tumbuh-tumbuhan. Melalui riset-riset itu mereka menemukan cukup banyak keajaiban-keajaiban yang membuat mereka mengakui adanya satu pencipta yang maha bijaksana, walaupun demikian, mereka tetap menyangkal adanya hari penggalian, kebangkitan kembali dan kehidupan akhirat serta mengingkari adanya surga dan neraka. Ketiga, filosof Teis (al-Ilahiyyun), mereka ini adalah filosof Yunani seperrti Sokrates, Plato dan Aristoteles. Sedemikian efektifnya, mereka membuktikan kesalahan filsafat Materialis dan Naturalis, sehingga pihak-pihak lain tidak berkesempatan untuk

${ }^{13}$ Lihat. Ahmad Daudi. op. cit., h. 98.

${ }^{14}$ Imam al-Ghazali. Mukhtasar ihva' Ulum al Din. Diterjemahkan oleh Irwan Kurniawan dengan judul “Mutiara Ihya' Ulumuddin” (Cer. II : Bandung : Mizan. 1997), h. 11-18. 
melakukan hal yang serupa. Aristoteles dengan tepat sekali telah menyanggah filosof-filosof sebelumnya termasuk Plato dan Sokrates.

Meskipun demikian, ia sendiri tidak mampu membebaskan diri dari kekafiran. Termasuk kelompok ini adalah al-Farabi dan Ibnu Sina. ${ }^{15}$

Itulah sebabnya dalam Tahafut al Falasifah-nya dengan penuh kesungguhan melakukan sanggahan-sanggahan terhadap teori-teori mereka untuk mempertahankan sendi-sendi pokok agama. Khususnya mengenai wujud dan keesaan Allah dan kebangkitan ukhrawi, yang menurutnya dipahami secara salah. Sanggahan-sanggahan tersebut dikemas dalam dua puluh masalah. Tiga diantaranya, oleh al-Ghazali dikategorikan sebagai "kufur" dan tidak satu pun aliran pemikiran kaum muslimin meyakininya, yaitu : 1) Tentang keqadiman alam, 2) Tuhan tidak mengetahui juz'iyah dan 3) tidak adanya kebangkitan jassmani. ${ }^{16}$

Pertama, Tentang Keqadiman Alam

Menurut al-Ghazali, para filosof sepakat bahwa alam ini qadim dan selalu ada (maujud) bersama Tuhan secara temporal terrjadi bersamaan dengannya sebagai akibat adanya Tuhan. Sebagaimana kebersamaan antara akibat dengan sebabnya atau seperti cahaya matahari dengan mataharinya.

Untuk mendukung teorinya itu, mereka mengemukakan alasan bahwa anggapan adanya Tuhan itu lebih dulu (tamaddun) dari adanya alam, mengandung dua kemungkinan.

Kemungkinan pertama, keterdahuluannya itu dari segi zat dan bukan dari segi zaman. Artinya, bahwa dari segi zaman (waktu) Tuhan itu ada bersamaan dengan alam. Hal ini dapat dilihat pada keterdahuluan gerak seseorang atas gerak bayangannya, atau keterdahuluan antara gerakan tangan di dalam air atas gerakan air. Pada keadaan semacam ini, kita dapat memastikan bahwa gerakan seseorang dengan gerakan bayangannya berada dalam waktu yang bersamaan. Karena kebersamaan dalam waktu, maka hanya ada dua kemungkinan, kedua-duanya qadim atau kedua-duanya hadits, atau dengan kata lain tidak bisa dikatakan yang satu qadim dan yang satu hadits. Karena kemungkinan kedua-duanya hadits tidak mungkin, maka yang benar adalah qadim. ${ }^{17}$

Kemungkinan kedua, bahwa keterdahuluan Tuhan atas alam ini secara zat dan secara temporal sekaligus. Jika dipahami bahwa keterdahuluan Tuhan atas alam ini secara temporal (dari segi zaman), maka sebelum adanya alam dan zaman, ada sebuah zaman ketika alam belum terwujud. Karena ketiadaan mendahului eksistensi (al-wujud). Dan karena Tuhan harus telah mendahului alam pada sebuah masa, yang berbatas akhir tetapi tidak pernah bermula, maka sebelum zaman haruslah ada zaman yang tak terhingga, dan ini mustahil. Oleh karena itu, mustahillah untuk mempercayai kebermulaan waktu. Dengan demikian keterdahuluan zaman yang merupakan ukuran gerak menjadi wajib dan

${ }^{15}$ Lihat. Imam al-Ghazal. Al-Munqiz min al-Dhalalah (Kairo : Maktabah al-Faqin li alNashr, 1961), h. 40-43.

${ }^{16}$ Lihat. Imam Al Ghazali. Tahafut al-falasifah (Cet. IV : Mesir : Dat al-Ma'rif, 1966), h. 86.

\footnotetext{
${ }^{17}$ Lihat., Ibid., h. 110
} 
keterdahuluan gerak juga wajib. Demikian pula keterdahuluan yang membuat waktu menjadi abadi, juga wajib. ${ }^{18}$

Untuk menjawab argumentasi para filosof tersebut, al-Ghazali menyatakan bahwa alam ini adalah baru dan terwujud karena iradat yang qadim. Perwujudan dan ketiadaannya dikehendaki sesuai dengan zaman yang ditentukan. Jadi, terwujudnya alam dimulai pada saat diadakan dan ketika belum dikehendaki, maka belum terwujud, karena terjadinya iradat yang qadim merupakan dasar perwujudan alam, zaman, menurut al-Ghazali juga mempunyai permulaan dan diciptakan. Adanya Tuhan dan alam tidak harus berhubungan dengan zaman, artinya bahwa Tuhan ada pada zaman-Nya sendiri dan tidak berhubungan dengan zaman lain. Menurutnya, sebelum zaman, sama sekali tidak ada zaman lain. Tuhan mendahului alam dan waktu, haruslah dipahami bahwa pada tahap pertama, Tuhan ada sendirian dan pada tahap kedua Tuhan ada dan alam ada bersama-sama Tuhan. ${ }^{19}$

Selanjutnya Al Ghazali mengemukakan bahwa kalau dikatakan alam ini qadim, berarti tidak diciptakan. Padahal yang tidak diciptakan hanya Allah. Jika demikian, maka alam juga Tuhan dan terdapatlah dua Tuhan. Hal ini membawa kepada faham syirik (politeisme). Lebih dari itu, tidak diciptakan bisa juga berarti perlu penciptaan yaitu Tuhan. Ini pun membawa kepada faham ateisme. Sementara politeisme dan ateisme bertentangan dengan dasar ajaran tauhid. ${ }^{20}$ Inilah yang mendorong al-Ghazali menuduh kafir para filosof yang percaya bahwa alam itu qadim.

Kedua, Allah Tidak Mengetahui Hal-Hal yang Juz'iyat.

al-Ghazali membagi pendapat filosof ke dalam dua kelompok. Pertama, berpendapat bahwa Tuhan hanya mengetahui dirinya sendiri dan tidak mengetahui selain-Nya. Kelompok kedua, termasuk di dalamnya Ibnu Sina yang berpendapat bahwa Tuhan juga mengetahui yang lain selain diri-Nya, tetapi pengetahuan-Nya itu bersifat kulli (secara universal) dan terikat dengan waktu. Alasan mereka adalah pengetahuan mengikuti objek pengetahuan. Apabila objek pengetahuan berubah, yang mengetahui juga berubah. Dengan demikian Tuhan dikatakan mengetahui juz'iyat, sedang yang juz'iyat selalu berubah, maka berarti Tuhan berubah dan ini mustahil. ${ }^{21}$

Berdasarkan pada pendapat filosof kelompok kedua, al-Ghazali berkesimpulan bahwa, menurut mereka Tuhan tidak mengetahui sesuatu yang terjadi pada manusia secara detail, Islam atau kafir. Tuhan hanya tahu tentang kekafiran dan keislaman manusia secara universal. Dengan demikian, Tuhan juga tidak mengetahui nama-nama rasul-Nya, Tuhan hanya tahu bahwa di bumi ini ada rasul. $^{22}$

Jika Tuhan tidak mengetahui hal-hal yang bersifat partikular atau juz'iyat, maka akan mengakibatkan pupusnya inayah Tuhan terhadap makhluk-Nya,

\footnotetext{
${ }^{18}$ Ibid

${ }^{19}$ Ibid., h. 96.

${ }^{20}$ Lihat. Harun Nasution. Filsafat Islam. Budhi Munawar (ed) "Kontekstualisasi Doktran Islam Dalam Sejarah" (Cet. II : Jakarta : Paramadina, 1995), h. 154.

${ }^{21}$ Lihat. Al-Ghazali, Tahafut, op. cit., h. 207.

${ }^{22}$ Ibid., h. 211.
} 
sekaligus Tuhan hanya mengetahui seorang manusia tidak secara terperinci, tetapi dalam wujud yang kulli, maka sudah barang tentu tidak ada hisab di akhirat. ${ }^{23}$

Pengetahuan Tuhan akan juz'iyat, demikian argumen al-Ghazali, tidak mesti harus mengakibatkan perubahan pada Tuhan, karena sesungguhnya Tuhan mengetahui segala sesuatu dengan ilmu yang satu dalam keaslian, keabadian-Nya, tanpa mengalami perubahan. Ia mencontohkan, jika seseorang yang ada di sebelah kanan anda yang menjadi titik pusat tidaklah berubah, yang berubah adalah seseorang itu sendiri (dari segi pertalian kedudukan). Kemudian lanjut al-Ghazali, mengapa mereka menolak pandangan yang mengatakan bahwa Tuhan mengetahui partikular (juz'iyat), kalau masalahnya hendak menafikan adanya perubahan pada Tuhan, maka sebetulnya para filosof tidak konsisten dengan prinsip mereka sendiri, yang mengatakan bahwa alam bersifat qadim seperti Tuhan, harus ditolak terjadinya perubahan dengan cara mengetahui juz'iyat, apabila pada alam bisa diterima adanya perubahan, maka seharusnya juga mau menerima perubahan pada Tuhan. $^{24}$

Golongan filosof berpendirian bahwa Tuhan tidak mengetahui hal-hal dan peristiwa-peristiwa kecil kecuali dengan cara yang umum (kulliyat, universal). Menurut al-Ghazali, Tuhan mengetahui segala sesuatu dengan ilmu yang satu dalam keasliannya, keabadian-Nya tanpa mengalami perubahan.

Ketiga, Tentang Kebangkitan Jasmani

Para filosof mengingkari adanya kebangkitan jasmani di akhirat, kembalinya roh ke dalam jasad serta adanya neraka dan surga secara materi. Setelah seseoarang mati, jiwanya akan kekal, jiwa suci di dunia akan merasakan kebahagian yang tiada tara. Sedangkan jiwa yang kotor akan merasakan kepedihan yang tiada tara. Apa yang disebut sebagai surga dan neraka, dan segala sesuatu yang dijanjikan Allah kepada manusia, bagi para filosof, tidaklah lebih dari sekedar simbol-simbol yang ditunjukan kepada orang awam.

Memang terdapat teks-teks syariat mengenai kebangkitan jasmani. Akan tetapi, hal itu hanya suatu simbol yang digunakan kepada orang awam, sebagaimana ayat-ayat dan tradis-tradisi tasybuh adalah suatu simbol yang digunakan karena keterbatasan pemahaman orang awam. Kesenangan di akhirat, menurut mereka bukanlah kesenangan fisik melainkan kesenangan spiritual, karena kesenangan tersebut adalah kesenangan yang tiada tara dan lebih utama. Hal ini dapat dibuktikan, Pertama, malaikat lebih mulia dari binatang, meskipun mereka tidak memiliki kesenangan jasmaniyah seperti hubungan seksual dan makan. Justru kesenangan malaikat terletak pada kesempurnaan dan ketiadaannya. Kedua, manusia sendiri seringkali mengutamakan kesenangan spiritual. Sebagai contohnya, orang sering terlena dengan berpikir sehingga melupakan makan. ${ }^{25}$

Untuk memperkuat pendapatnya, para filosof mengemukakan alasan, bahwa pengandaian kembalinya jiwa seseorang ke dalam jasad tidak lepas dari tiga kemungkinan. Pertama, jiwa itu hakekatnya tidak ada pada manusia dan yang ada hanya jasad dan kehidupan (al-hayah). Ketika manusia itu mati hilanglah al-hayah. Kebangkitan manusia ialah kembalinya jasad dan al-hayah kepadanya.

\footnotetext{
${ }^{23}$ Ahmad Daudy. op.cit., h. 207.

${ }^{24}$ Lihat. Ibid., h. 215.

${ }^{25}$ Lihat. Ibid., h. 284
} 
Kemungkinan ini tidak dibenarkan oleh para filosof karena hal itu bukan lagi berarti kembalinya roh ke jasad manusia. Melainkan pencipta baru. Kedua. Bahwa ilmu manusia itu tetap ada sesudah manusia itu mati dan pada hari kiamat ia kembali lagi ke jasad manusia. Yaitu dengan terhimpunnya kembali jasad-jasad pada dirinya. Kemungkinan ini pun tidak bisa diterima mengingat jika dianggap terhimpunnya bagian-bagian jasad itu selama hidupnya, maka pertanyaan yang muncul adalah bagaimana dengan orang yang memakan daging manusia. Karena jasad manusia itu terdiri dari berbagai jiwa. Apakah mungkin akan dibangkitkan berbagai jiwa pada satu jasad. Tentu hal ini tidak mungkin. Oleh karena itu, kebangkitan jasmani adalah mustahil. Ketiga, bahwa yang terpenting adalah kembalinya jiwa ke dalam jasad manusia. Dan hal itu apakah dari bagian-bagian tubuhnya ataukah dari bagian yang lain. Kemungkinan ini pun tidak dapat diterima. Karena menurut mereka materi itu terbatas bilangannya, sedangkan jiwa tidak terbatas. Oleh karena itu, jasad manusia tidak dapat menampung jiwa. ${ }^{26}$ Disamping itu, pandangan ini menurut para filosof mengandung unsur reinkarnasi. ${ }^{27}$ Sementara, reinkarnasi tidak dapat diterima.

Dalam hal keabadian jiwa, dan keutamaan kebahagiaan spiritual daripada kebahagiaan jasmani. al-Ghazali sepakat dengan para filosof, karena syariat mengisyaratkan hal tersebut. Akan tetapi, menurut al-Ghazali hal ini tidak mengkonsekuensikan penafian kebahagiaan atau kesengsaraan jasmani di akhirat. Justru kebahagiaan atau kesengsaraan jasmani akan menyempurnakan kebahagiaan atau kesengsaraan spiritual. Akan tetapi, menurut Al Ghazali tidaklah dapat mengetahui tentang jiwa atau kebahagiaan dan kesengsaraan di akhirat. Semua ini merupakan wilayah otoritas wahyu, maka tidak dapat diterima. ${ }^{28}$

Selanjutnya, bagi al-Ghazali, ayat-ayat al-Qur'an serta tradisi-tradisi yang mengandung tasybih, khususnya yang mendeskripsikan mengenai surga dan neraka serta detail-detailnya, bukanlah merupakan wilayah $t a$ 'wil. Jadi, harus dipahami secara literal. Dengan demikian, kehidupan di akhirat tidaklah bisa dipahami sebagai kehidupan spiritual saja melainkan juga secara jasmani. ${ }^{29}$

Sedangkan, untuk menjawab argumentasi para filosof mengenai kemustahilan-kemustahilan kebangkitan jasmani sebagaimana dikemukakan sebelumnya, tampaknya inti jawaban al-Ghazali didasarkan atas sifat kemahakuasaan Tuhan bahwa Tuhan mampu menciptakan segala sesuatu dari tiada. Karena itu, ia pun mampu membangkitkan kembali tubuh dan tulangbelulang manusia yang telah hancur menjadi tanah ke dalam bentuk semula. ${ }^{30}$

Dari uraian di atas dapat ditarik suatu pengertian bahwa yang dikehendaki para filosof adalah kemungkinan yang rasional tentang kebangkitan dan kehidupan di akhirat. Para filosof dan al-Ghazali sama-sama meyakini adanya "kebangkitan jasmani" di akhirat itu. Perbedaan adalah bentuk dan bagaimana cara kebangkitan

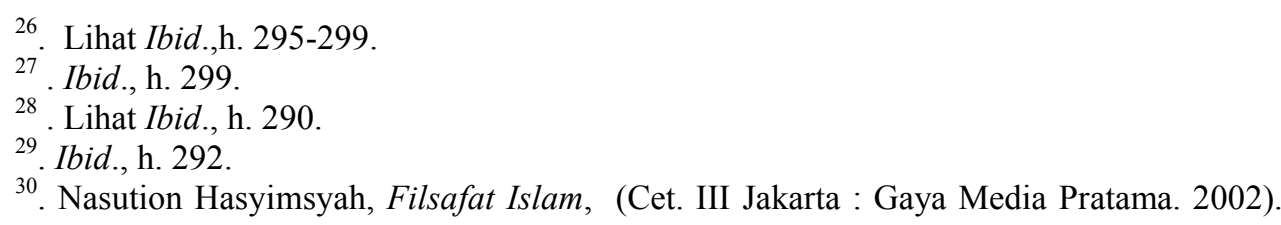
H. 86 
itu. Bagi filosof secara rohaniah, sedangkan Al Ghazali secara jasmani dan rohaniah.

\section{KESIMPULAN}

Dari uraian tersebut di atas, maka dapat disimpulkan sebagai berikut:

1. Kritikan al-Ghazali terhadap filosof sebagaimana yang dirumuskan dalam Tahafut al Falasifah seringkali dijadikan alasan bagi reinkarnasi pemikiran di dunia Islam, karena meskipun kritikan tersebut terbatas pada teori metafisika (Al-Ilahiyat), akan tetapi sering digeneralisir sebagai kritik terhadap keseluruhan kajian filsafat, sehingga filsafat tercampakkan ke posisi marginal dalam pemikiran Islam. Untuk itu, perlu adanya klarifikasi dan upaya meluruskan kembali persepsi tersebut, khususnya dikalangan akademisi.

2. Ada dua puluh masalah yang disajikan baik kritikan oleh al-Ghazali. Tujuh belas masalah yang dikategorikannya sebagai bid'ah dan tiga lainnya dicap kafir. Ketiga masalah tersebut itu adalah keqadiman alam, ketidaktahuan Tuhan terhadap hal yang kecil (juz'iyat) dan tidak adanya kebangkitan jasmani.

\section{DAFTAR PUSTAKA}

Abdullah. Amin. Agama Normativitas atau Historisitas. Cet. I. Yogyakarta: Pustaka Pelajar), 1996.

Averoes. Tahafut al Tahaful: The Incoherence of The Incoherence. Oxford: The University Press, 1954.

Daudy, Ahmad. Kuliah Filsafat Islam. Cet. III. Jakarta: Bulan Bintang, 1992.

Fakhry, Majid. A History of Islamic Philosophy. Diterjemahkan oleh R. Mulyadhi Kartanegara dengan judul Sejarah Filsafat Islam. Cet. I. Jakarta: Pustaka Jaya, 1987.

Ghazali, Abu Hamid Muhammad bin Muhammad. Mukhtasar Ihya' Ulum al Din, diterjemahkan oleh Irwan Kurniawan dengan Judul "Mutiara Ihya' Ulumuddin". Cet. I. Bandung: Mizan, 1997. , . Tahafut al Falasifah. Cet. IV. Mesir: Dar al Ma'arif, 1966. , . Maqashid al Falasifah. Edisi Sulaiman Dunya. Mesir: Dar al Ma'arif, t. th. , al Munqiz min al Dhalal. Kairo: Makatabah al Faqin Ii al Nashr.

Majid, Nurcholish. Khazanah Intelektual Islam. Cet. II. Jakarta: Bulan Bintang, 1985.

Musa, Yusuf. Bayn al Din wa al Falsafah fi Ra'yi Ibnu Rusyd wa al Falasifah al Asr al Wasith. Cet. I. Mesir: Dar al Ma'arif, t. th.

Nasution, Harun. Filsafat dan Mistisisme dalam Islam. Cet. V. Jakarta: Bulan Bintang, 1975. 
. Islam Ditinjau dari Berbagai Aspeknya. Jilid II, Cet. VI. Jakarta: UI_Press, 1986.

, . Filsafat Islam, dalam Budhi Munawar Rachman ed. "Kontekstualisasi Doktrin Islam dalam sejarah". Cet. II. Jakarta: Paramadina, 1995.

Nasution, Hasyimsyah. Filsafat Islam. Cet. III. Jakarta: Gaya Media Pratama, 2002.

Watt, W. Montgomery. The Influenlce of Islam on Medieval Europe. Diterjemahkan oleh Henro Prasetio dengan judul "Islam dan Peradaban Dunia: Pengaruh Islam atas Eropa Abad Pertengahan”. Jakarta: Gramedia, 1995. 